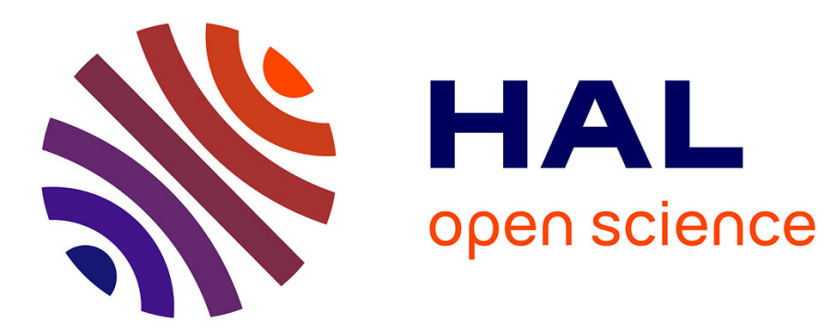

\title{
TEM00 high efficiency surface emitting laser diode longitudinally pumped Nd:YVO4 laser
}

\author{
G. Feugnet, M. Schwarz, C. Larat, J. Pocholle, M. Papuchon
}

\section{To cite this version:}

G. Feugnet, M. Schwarz, C. Larat, J. Pocholle, M. Papuchon. TEM00 high efficiency surface emitting laser diode longitudinally pumped Nd:YVO4 laser. Journal de Physique IV Proceedings, 1994, 04 (C4), pp.C4-605-C4-605. 10.1051/jp4:19944155 . jpa-00252611

\section{HAL Id: jpa-00252611 https://hal.science/jpa-00252611}

Submitted on 1 Jan 1994

HAL is a multi-disciplinary open access archive for the deposit and dissemination of scientific research documents, whether they are published or not. The documents may come from teaching and research institutions in France or abroad, or from public or private research centers.
L'archive ouverte pluridisciplinaire HAL, est destinée au dépôt et à la diffusion de documents scientifiques de niveau recherche, publiés ou non, émanant des établissements d'enseignement et de recherche français ou étrangers, des laboratoires publics ou privés. 


\title{
TEM $_{00}$ high efficiency surface emitting laser diode longitudinally pumped Nd: $\mathrm{YVO}_{4}$ laser
}

\author{
G. FEUGNET, M. SCHWARZ, C. LARAT, J.P. POCHOLLE and M. PAPUCHON
}

THOMSON CSF, Laboratoire Central de Recherches, Domaine de Corbeville, 91404 Orsay, France

The laser diodes are the solid-state lasers most efficient pump sources. Monolithic Surface Emitting Laser Diode (M-SELD) has been validated with laser diode structures grown on an engraved $\mathrm{GaAs}$ substrate $[1,2]$. The groove edges are $45^{\circ}$ etched to form an integrated mirror which reflects the output beam normally to the epitaxial plane. We report first results on $\mathrm{Nd}: \mathrm{YVO}_{4}$ laser longitudinally pumped by a M-SELD. This pumping scheme allows higher conversion efficiency than the transverse one (M-SELD side pumped Nd:YAG slab results have already been published $[3,4])$. The $\mathrm{Nd}: \mathrm{YVO}_{4}$ high absorption coefficient minimise the pump power deposition volume.

The M-SELD was made by Thomson-CSF Semiconducteurs Spécifiques (TCS). The output energy is $3.8 \mathrm{~mJ}$ (respectively $6.8 \mathrm{~mJ}$ ) per $100 \mu \mathrm{s}(200 \mu \mathrm{s})$ long pulse at $50 \mathrm{~Hz}$ repetition rate on a $3 \times 3.2 \mathrm{~mm}^{2}$ surface (120 emitters). The spectral width is about $4 \mathrm{~nm}$. The optical beam divergence is $\sim 15^{\circ}$ (FWHM) in each direction with a pedestal due to light unreflected by the integrated mirrors. A small concavity of these mirrors induces the reduction of the currently large divergence $\left(\sim 50^{\circ}\right)$ in the direction perpendicular to the epitaxial plane. The M-SELD light is concentrated into the laser material by two aspheric lenses (1/3 magnification). The coupling efficiency defined as the ratio between the energy incident on the laser crystal and the M-SELD emitted energy is $60 \%$, limited by the optical beam pedestal and the laser cavity mirror $\left(M_{1}\right)$ $90 \%$ transmission at $808 \mathrm{~nm}$.

The AR coated $1 \%$ at. a-cut $\mathrm{Nd}: \mathrm{YVO}_{4}$ crystal is $3 \mathrm{~mm}$ long. The pump beam is $\pi$ polarised. The $90 \mathrm{~mm}$ long laser cavity is formed by a $10 \mathrm{~m}$ radius of curvature high reflector $\mathrm{M}_{1}$ and a $7 \%$ transmission flat output mirror $\mathrm{M}_{2}$. The laser material is placed $2 \mathrm{~mm}$ above $\mathrm{M}_{1}$. Output energy of $0.74 \mathrm{~mJ}$ was obtained with a $2.3 \mathrm{~mJ}$ incident pump energy (100 $\mu$ s long pump pulses). Slope and optical/optical efficiencies are $35 \%$ and $32 \%$ respectively. The mode was found to be nearly diffraction limited with a $\mathrm{M}^{2}$ value of 1.1 .

In conclusion, we have demonstrated what is to our knowledge the first $\mathrm{Nd}: \mathrm{YVO}_{4}$ laser longitudinally pumped by a Monolithic Surface Emitting Laser Diode. Works are being carried on to increase the coupling efficiency through energy distribution characteristic improvements. The authors would like to thank B. Groussin, A. Parent, T. Fillardet and C. Carriere from TCS for providing the M-SELD and for their technical assistance. This work was partly supported by the French Ministère de l'Enseignement Supérieur et de la Recherche.

[1] S. S. Ou, M. Jansen,J. J. Yang, L. J. Maws and T. J. Roth, Appl. Phys. Lett., 59, 2085 (1991).

[2] B. Groussin, F. Pitard, A. Parent and C. Carriere, Electron. Lett. , 29, 370 (1993).

[3] C. Larat, M. Schwarz and J. P. Pocholle, Electron. Lett., 28, 1630 (1992).

[4] C. Larat, M. Schwarz, G. Feugnet and J. P. Pocholle, in Proceedings of the 1993 Advanced Solid State Lasers and Compact Blue-Green Conference Lasers, (Optical Society of America, Washington DC,1993 ). 